ACTA THERIOLOGICA

Vol. 25, 28: 349-363, 1980

BISIONIANA, LXXVI

\title{
Correlation of Skull Dimensions in the European Bison
}

\author{
Franciszek KOBRYNCZUK \& Tadeusz ROSKOSZ
}

Kobryńczuk F. \& Roskosz T., 1980: Correlation of skull dimensions in the European Bison. Acta theriol., 25, 28: 349-363 [With 2 Tables \& 4 Figs.]

The skull of 84 European bisons (Bison bonasus Linnaeus, 1758) obtained from reserves were analysed. Correlation coefficients of twelve linear measurements were tested. Variation in the dimensions in the juvenile animals is greater than for adult ones. Correlation coefficients for juvenile skull dimensions are high and they decrease in older European bisons. Some dimensions e.g. mandibular change with age differently in males and in females. In adult females there are far fewer non-significant correlations in comparison to males.

[Inst. Anim. Physiol., Agric. Acad., Nowoursynowska 166, 02-766 Warszawa]

\section{INTRODUCTION}

The question of postnatal development of mammal skulls continues by a large number of authors. Such studies have been carried out chiefly on small mammals ( $\mathrm{C}$ a boń-R a czyńska, 1964; K an ep, 1967; Ruprecht, 1971, 1972a, 1974; Buchalczyk \& Ruprecht, 1977), concentrating on problems of diversity in skull parameters, its sex dimorphism, developmental correlation of features etc. A considerable amount of attention has been devoted to the taxonomic values of the dimensions examined, to regression equations, which in all have become a new instrument in craniometry and a most suitable method in paleontology. The authors referred to above have drawn attention to the allo- and isometric growth of the skull, which should be of importance in all studies on development of the sensory organs, brain and also the initial parts of the respiratory and alimentary tracts. Some researchers (Wyrost \& K u charczy k, 1967; P tas ińskaUrbańska, 1972; Strzałko \& Malinowski, 1972) searched for correlations between certain features of the mammalian skull and dimensions of selected organs or the whole organism.

The authors of the present study decided to carry out studies on the skull of the European bison, paying particular attention to analysis of correlation coefficients of its dimensions.

Up to the present studies concerned with the skull of this animal (Empel, 1962) have concentrated primarily on morphology and 
analysis of parameters based on Duerst's work (1926). The report by $\mathrm{Ruprecht}(1972 \mathrm{~b})$ contributed to statistical interpretation of skull characteristic in the European bison.

\section{MATERIAL AND METHODS}

The study material consisted on the macerated skulls of 84 European bison (Bison bonasus Linnaeus, 1758) (45 males and 39 females) aged from one year to 23 years, obtained from reserve-bred animals. On the basis of the Bison Pedigree Books (Ża biński, 1947-65; Ża biński \& Raczyński, 1972) this material was divided into two groups according to age, separately for each sex. The first group (I) - of 10 males and 11 females, termed the juvenile group, consisted of skulls of individuals from one to 5 years, of age and the second (II) group of 35 males and 28 females, termed adult group, skulls of bison over 5 years old.

Twelve linear measurements, either directly or in projection with accuracy to $1 \mathrm{~mm}$, were made on these skulls, taking the study by Duerst (1926) as a basis, as follows (Fig. 1):
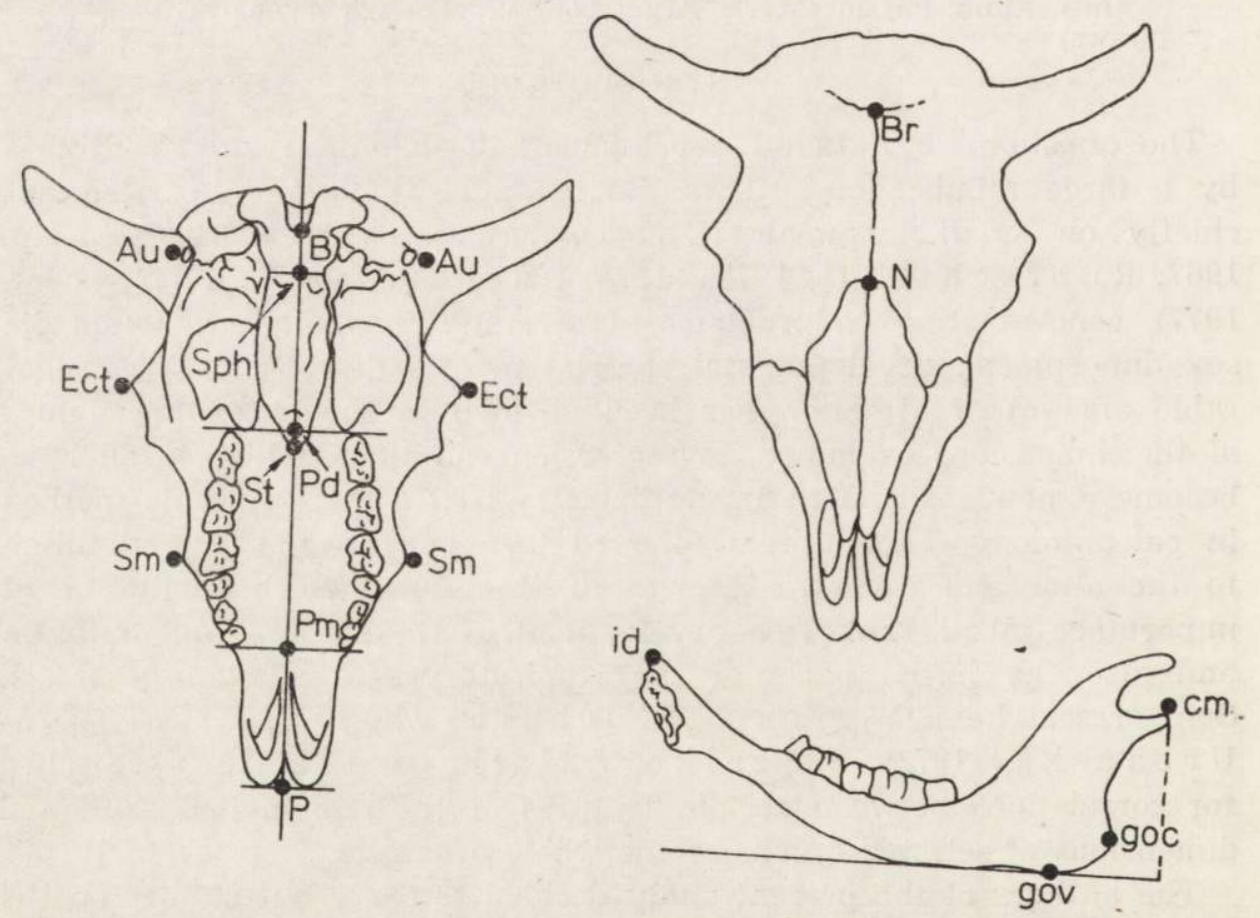

Fig. 1. Measurements points on the bison skull after Duerst (1926)

1. BP (Basion-Prosthion) - length of skull base, 2. BSt (Basion-Staphylion) length of base of neurocranium, 3. StP (Staphylion-Prosthion) length of base of viscerocranium, 4. PmP (Praemolare-Prosthion) - length of toothless margin, 
5. PdPm (Postdentale-Praemolare) - length of toothrow from $P_{1}$ to $M_{3}, 6$. gocid (Gonion caudale-Infradentale) - length of mandible from its angle, 7. EctEct (Ectoorbitale-Ectoorbitale) - interorbital breadth, 8. $\mathrm{SmSm}$ (Supramolare-Supramolare) - breadth of viscerocranium, 9. AuAu (Auriculare-Auriculare) breadth of neurocranium, 10. StN (Staphylon-Nasion) - height of viscerocranium, 11. $\mathrm{SphBr}$ (Sphenobasion-Bregma) - height of neurocranium, 12. govcm (Gonion ventrale-Condylion mediale) - height of mandible to condyle (in projection).

Among the 12 skull parameters mentioned the skull as a whole had two measurements: length of skull base and interorbital breadth ( 1 and 7$)$, the neurocranium three: length, breadth and height $(2,9,11)$, the viscerocranium without the mandible five: length, breadth and height $(3,8,10)$ and length of the toothrow and toothless margin $(4,5)$. The mandible was defined by two parameters: length and height $(6,12)$. In this way the chosen features of the skull give the closest picture of its stereometric structure as a whole and its two functional parts: the neuro- and viscerocranium.

The dimensions for each group were tested statistically and set out in Table 1. Individual values of these dimentions were used to calculate 66 correlation coefficients $(r)$ for each group for corresponding pairs. These coefficients and differences between them in the appropriate groups were tested for significance at two levels: $p \leqslant 0.05$ and $p \leqslant 0.01$ (Table 2). These results formed a basis for examining the correlation connections of the bison skull from the aspects of age and sex dimorphism. The correlation coefficients were arranged by means of Czekanowski's diagrams (1913), grouping in them only significant coefficients (Fig. 2, 3), while the persistence of correlation connections was traced by constructing Terentiev's pleiads (1943, Fig. 4).

\section{RESULTS}

Variation in the dimensions of the European bison skulls in the juvenile group is greater than for the adult group (Table 1), and only

Table 1

Mean values of skull dimensions in the European bison $(\mathrm{mm})$.

\begin{tabular}{|c|c|c|c|c|c|c|c|c|}
\hline & \multicolumn{4}{|c|}{ Group I } & \multicolumn{4}{|c|}{ Group II } \\
\hline & $\begin{array}{c}\text { Males, } n \\
\overline{\mathrm{x}} \pm \mathrm{SD}\end{array}$ & $\begin{array}{l}=11 \\
\text { C.v. }\end{array}$ & $\begin{array}{c}\text { Females, } \mathrm{n} \\
\overline{\mathrm{x}} \pm \mathrm{SD}\end{array}$ & $\begin{array}{l}\text { C.v. } \\
\text { C. }\end{array}$ & $\begin{array}{l}\text { Males, } \mathrm{n} \\
\overline{\mathrm{x}} \pm \mathrm{SD}\end{array}$ & $\begin{array}{c}1=35 \\
\text { C.v. }\end{array}$ & $\begin{array}{l}\text { Females, } \mathrm{n} \\
\overline{\overline{\mathrm{x}} \pm \mathrm{SD}}\end{array}$ & $\begin{array}{l}n=28 \\
\text { C.v. }\end{array}$ \\
\hline$B P$ & $421.5 \pm 41.1$ & 9.8 & $400.0 \pm 44.1$ & 11.0 & $482.7 \pm 21.5$ & 4.4 & $454.0 \pm 13.4$ & 3.0 \\
\hline$B S t$ & $170.3 \pm 20.1$ & 11.8 & 14.3 & 9.3 & \pm 12.6 & 6. & \pm 7.9 & 4.5 \\
\hline StP & $256.2 \pm 22.6$ & 8.8 & \pm 30.8 & 12.4 & $295.1 \pm 9.2$ & 3.1 & $280.1 \pm 8.1$ & 2.9 \\
\hline$P m P$ & $125.2 \pm 10.7$ & 8.5 & $123.0 \pm 13.6$ & 11.0 & $148.3 \pm 6.2$ & 4.2 & $139.0 \pm 7.1$ & 5.1 \\
\hline$P d P m$ & $137.0 \pm 11.8$ & 8.6 & $130.4 \pm 16.6$ & 12.7 & $139.9 \pm 6.6$ & 4.7 & $133.6 \pm 4.6$ & 3.4 \\
\hline goci & $357.9 \pm 34.9$ & 9.7 & +344 & 99 & $409.1 \pm 19.2$ & 4.7 & $292.2 \pm 11.7$ & 4.0 \\
\hline EctEct & $258.8 \pm 38.8$ & 15.0 & \pm 33.5 & 14.9 & $319.7 \pm 13.9$ & 4.3 & $269.1 \pm 11.8$ & 4.4 \\
\hline$S m S m$ & $152.7 \pm 16.6$ & 10.9 & \pm 16.9 & 11.9 & \pm 9.3 & 5.1 & $168.3 \pm 7.0$ & 4.1 \\
\hline$A u A u$ & $201.5 \pm 31.4$ & 15. & \pm 22.0 & 12 & \pm 10.4 & 4.2 & $208.0 \pm 6.7$ & 3.2 \\
\hline StN & $147.5 \pm 19.0$ & 12. & & 14.3 & \pm 7.1 & 4.1 & $155.7 \pm 4.7$ & 2.9 \\
\hline$S p h B r$ & $140.6 \pm 16.8$ & 11.9 & 12 & 11 & $5 \pm 6.0$ & 3.8 & $142.5 \pm 4.6$ & 2.1 \\
\hline govem & $105.3 \pm 12.3$ & 11.7 & $101.1 \pm 11.0$ & 10.9 & $126.5 \pm 8.4$ & 6.6 & $122.5 \pm 7.4$ & 6.0 \\
\hline
\end{tabular}

slightly different in the two sexes. In juvenile males three out of the 12 dimensions with lowest variability were measurements of length; 
of the toothless margin, the toothrow and viscerocranium ( $P m P$, $P d P m$ and $S t P$ ) and in females the length of neurocranium and the two mandibular measurements (BSt, gocid, govcm). The two dimensions with maximum variability in both sexes are the interorbital breadth and height of the viscerocranium (EctEct, StN): the third in males is the breadth of the neurocranium $(A u A u)$ and in females - the

Table 2

Significance of correlation coefficients and differences between them at levels of $p \leqslant 0.05(+)$ and $p \leqslant 0.01(++)$.

$r_{\sigma^{7} j}$ - correlation coefficients of luvenile males

$r_{O_{j}}$ - correlation coefficients of juvenile females

$r_{\mathrm{C}^{*} \mathrm{a}}$ - correlation coefficients of adult males

$r_{\mathrm{O}_{\mathrm{a}}}$ - correlation coefficients of adult females

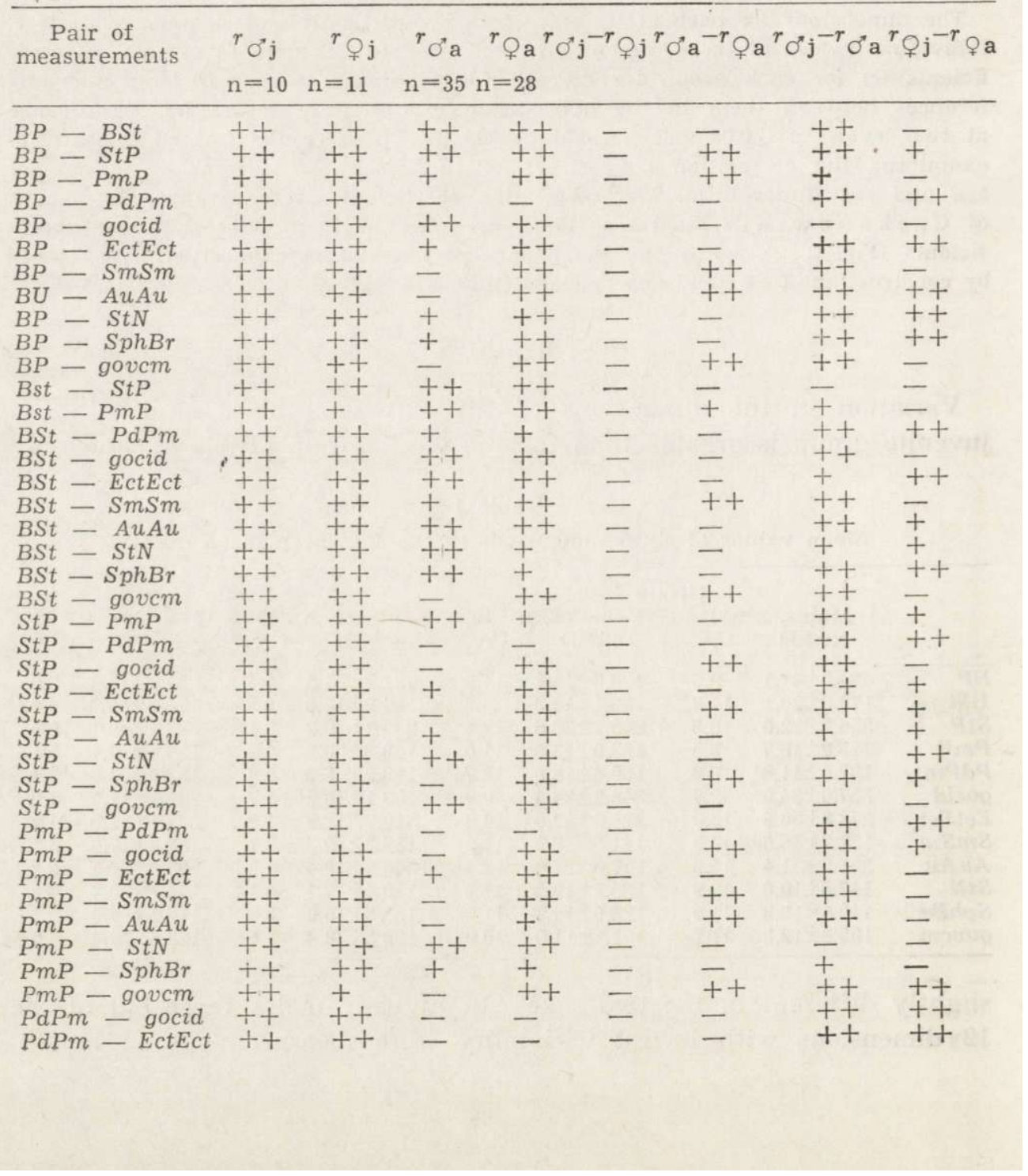




\begin{tabular}{|c|c|c|c|c|c|c|c|c|}
\hline$P d P m-S m S m$ & ++ & $+t$ & - & ++ & - & ++ & ++ & + \\
\hline$P d P m-A u A u$ & ++ & $+t$ & - & - & - & - & & ++ \\
\hline$P d P m-S t N$ & $+t$ & ++ & - & + & - & ++ & & - \\
\hline$P d P m-S p h B r$ & ++ & ++ & - & + & - & ++ & & + \\
\hline$P d P m-g o v c m$ & $+t$ & $+1+$ & - & - & - & - & & \\
\hline gocid - EctEct & ++ & ++ & - & ++ & - & ++ & & \\
\hline gocid - SmSm & ++ & ++ & - & $+t$ & - & ++ & & \\
\hline gocid - $A u A u$ & $+t$ & ++ & - & + & - & ++ & & \\
\hline gocid - StN & ++ & & - & ++ & - & ++ & & \\
\hline gocid - SphBr & ++ & ++ & - & ++ & - & & & \\
\hline gocid - govcm & $+t$ & ++ & ++ & - & - & $+t$ & & \\
\hline EctEct - SmSm & ++ & ++ & ++ & ++ & - & 一 & t & , \\
\hline EctEct - AuAu & $+t$ & ++ & $+t$ & ++ & - & - & & \\
\hline EctEct - StN & ++ & ++ & ++ & $+t$ & - & - & + & \\
\hline EctEct $-S p h B r$ & ++ & ++ & $+t$ & ++ & - & - & - & + \\
\hline EctEct - govcm & $+t$ & ++ & - & $+t$ & $+t$ & $+t$ & & - \\
\hline$S m S m-A u A u$ & $+t$ & $+t$ & ++ & $+t$ & - & - & + & \\
\hline$S m S m-S t N$ & ++ & ++ & ++ & ++ & - & & - & \\
\hline$S m S m-S p h B r$ & ++ & ++ & ++ & ++ & - & - & & $+t$ \\
\hline $\mathrm{SmSm}-\mathrm{govcm}$ & ++ & ++ & - & ++ & - & ++ & $t$ & - \\
\hline$A u A u-S t N$ & ++ & ++ & ++ & + & 一 & - & t & -+ \\
\hline$A u A u-S p h B r$ & ++ & ++ & ++ & ++ & - & - & $+t$ & ++ \\
\hline$A u A u-S p h B r$ & $+1+$ & ++ & ++ & ++ & - & - & ++ & \\
\hline$S t N-S p h B r$ & ++ & ++ & $+t$ & $+t$ & - & - & + & \\
\hline StN - govcm & ++ & ++ & ++ & $+t$ & - & - & & \\
\hline SphBr - govem & ++ & ++ & + & + & - & - & t & \\
\hline
\end{tabular}

length of the toothrow (PdPm) (Table 1).

Correlation coefficients for juvenile skull dimensions are high and all statistically significant $(p \leqslant 0.01$, Table 2$)$, with the exception of the following pairs: BSt-PmP, PmP-PdPm, Pm-govcm in females, where this significance is lesser $(p \leqslant 0.05)$. With two exceptions, no statistically significant differences were found between the coefficients of correlattion for juvenile males and females. The two exceptions are formed by the pairs: EctEct-govcm and AuAu-govcm, in which the correlation in males is greater than in females. In the diagrams drawn up on the basis of mean values of correlation coefficients the following occupy the three middle places in the case of males: interorbital breadth, breadth of viscerocranium and mandible length (EctEct, $A u A u$, gocid). With females these places were occupied by interorbital breadth (EctEct) and in addition the length of skul base and height of the viscerocranium $(B P, S t N)$. In turn the three peripheral places in these diagrams (Fig. 2) are occupied equally for both sexes by length of the toothless margin and tothrow length $(\mathrm{PmP}, \mathrm{PdPm})$ and breadth of viscerocranium $(\mathrm{SmSm})$ - males and height of mandible (govcm) in females.

All pairs of features come within pleiads for juvenile bison (Fig. 4), with $r>0.6$, while with $r>0.8$ loss of two pairs only were found for males: BSt-PdPm and $P d P m-S m S m$, whereas ten pairs are missing in females. In six of these the height of the mandibular condyle $($ govcm) does not exhibit correlation with the following parameters: BSt, StP, 
354

\begin{tabular}{|c|c|c|c|c|c|c|c|c|c|c|c|c|}
\hline MALES & 1 & 2 & 3 & 4 & 5 & 6 & 7 & 8 & 9 & 10 & 11 & 12 \\
\hline $1 \mathrm{SmSm}$ & & 0 & & & & & 0 & & & & & \\
\hline 2 StP & .867 & & 0 & 0 & 0 & 0 & & 0 & & & & \\
\hline $3 \mathrm{BSt}$ & 8. & .883 & & & & & & & & & & \\
\hline 4 govcm & .933 & .893 & .945 & & & & & & & & & $C$ \\
\hline $5 \mathrm{AuAu}$ & .956 & .879 & .963 & 986 & & & & & & & 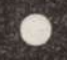 & 0 \\
\hline 6 EctEct & .932 & .899 & .954 & 986 & 982 & & & & & & & O \\
\hline 7 gocid & .893 & .949 & .969 & .979 & .942 & .958 & & & & & & $\mathrm{C}$ \\
\hline $8 \mathrm{SphBr}$ & .936 & .894 & .962 & .967 & .979 & 979 & .942 & & & & 0 & 0 \\
\hline $9 \mathrm{StN}$ & 965 & 919 & .926 & .934 & 965 & .937 & .934 & 943 & & & 0 & 0 \\
\hline $10 \mathrm{BP}$ & .889 & .945 & 947 & 908 & 936 & .912 & .948 & .942 & .949 & & & . \\
\hline $11 \mathrm{PmP}$ & .846 & .957 & .901 & .928 & .895 & .927 & .960 & .884 & .877 & .902 & & 0 \\
\hline $12 \mathrm{PdPm}$ & 790 & .913 & .778 & .823 & .812 & .873 & .880 & .842 & 861 & .820 & .861 & \\
\hline
\end{tabular}

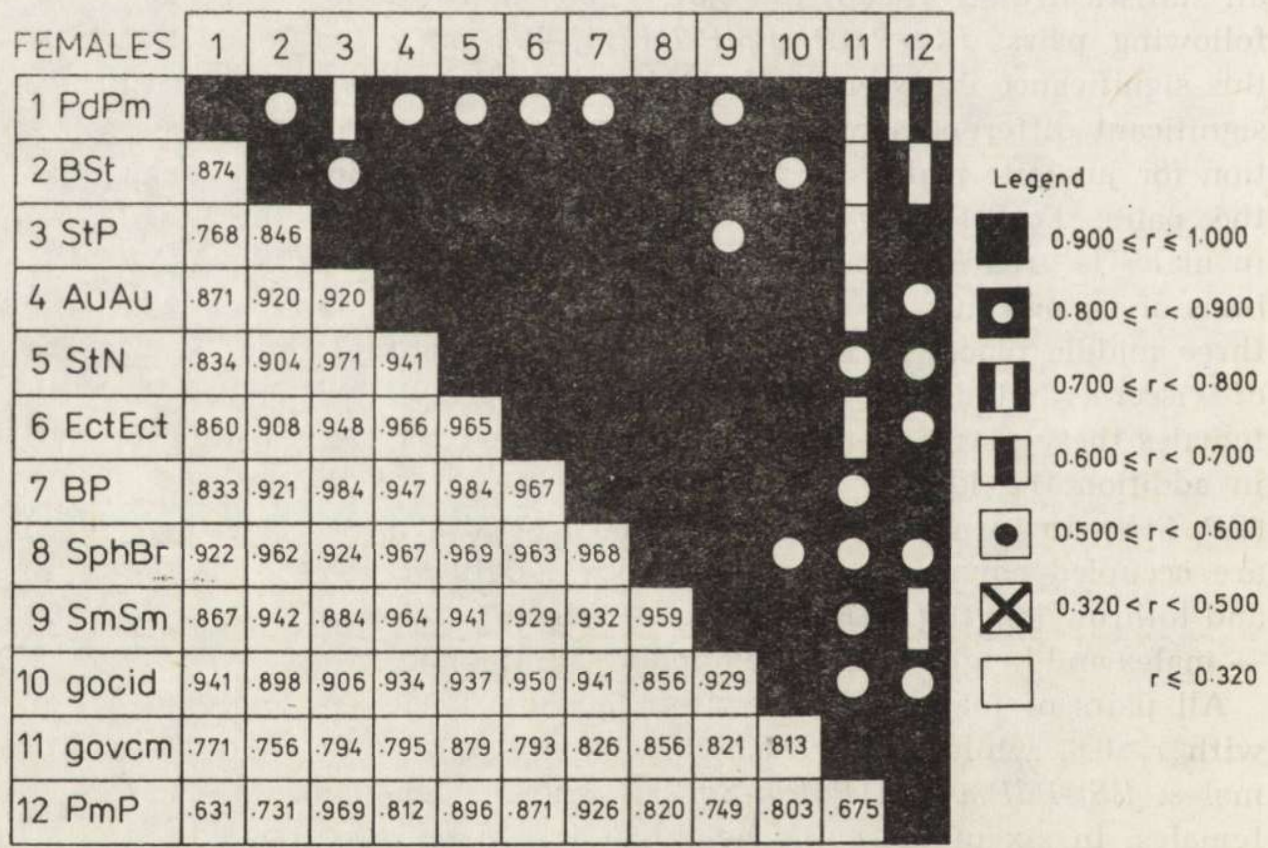

Fig. 2. Diagram of correlation coefficients for skull dimensions in juvenile bison. 
$P m P, P d P m, E c t E c t, A u A u$, the further four pairs are $P m P-S m S m$, $P d P m-P m P, P m P-B S t, P d P m-S t P$. It is clear from the above that in juvenile females with the same degree of correlation it is primarily the pairs connected with the mandibular condyle and certain pairs with $P m P$ and $P d P m$ which are lacking.

In adult bison the least variability (Table 1), equally for both sexes, is the length of base of the viscerocranium and its height, and height of the neurocranium ( $S t P, S t N, S p h B r)$. Most variable in this respect, in both sexes, are length of base of neurocranium and height of the mandibular condyle (BSt, govcm) and in addition, in males, the breadth of the viscerocranium $(\mathrm{SmSm})$ and length of the toothless margin $(P d P m)$ in females.

Many of the correlation coefficients in adult males are not significant (Table 2, Fig. 3). Among such are: correlations of all parameters with length of toothrow, correlations of all parameters with mandibular length (gocid) with the exception of the pair gocid-BSt and gocid-BP. correlations of all parameters with height of mandibular condyle (govcm), with the exception of the pairs: govcm-StN, govcm-Sph-Br, govcm-StP. In addition in adult males the breadth of the viscerocranium $(\mathrm{SmSm})$ is not correlated with: PmP, StP and BP. In turn a lack of relation is observed between: base of the skull and breadth of the neurocranium $(B P-A u A u)$, breadth of the neurocranium and length of toothless margin (AuAu-PmP), and between length of the base of the viscerocranihm and height of the nehrocranium ( $\mathrm{SphBr}-\mathrm{StP})$.

In adult females there are far fewer non-significant correlations. As in the case of males, the length of the toothrow does not exibit ccirelation with any of the dimensions except height and breadth of the viscerocranium ( $S t N, S m S m)$.

Some of the correlation coefficients in the two sexes, inter alia, those not significant, have negative values. Significant coefficients with negative values occur only in females and apply to the following pairs: $P d P m-S t N$ and PdPm-SmSm.

When comparing the absolute values of 66 pair of correlation coefficients for adult males and females (Table 2) we find that in 27 cases the coefficients are statistically significantly greater in females than in males. In the remaining cases pairs of coefficients $r$ do not differ significantly. The situation in which these coefficients would be greater in males does not therefore occur.

As is known from this method, each parameter forms 11 pairs with the pthers. It fran be seen from table 2 column 7 that in females mandibular length (gocid) in as many as 8 pairs exhibits higher correlation than in males and furthermore: mandibular height $(\mathrm{govcm})$ 


\begin{tabular}{|c|c|c|c|c|c|c|c|c|c|c|c|c|}
\hline MALES & 1 & 2 & 3 & 4 & 5 & 6 & 7 & 8 & 9 & 10 & 11 & 12 \\
\hline 1 gocid & & & 0 & & & & & & & & & \\
\hline $2 \mathrm{SmSm}$ & & & & & & & & & & & & \\
\hline $3 \mathrm{BP}$ & .880 & & & & & & & & & & & \\
\hline $4 \mathrm{AuAu}$ & & 695 & & & & & & & & & & \\
\hline $5 \mathrm{BSt}$ & .447 & 369 & .602 & .617 & & 0 & & & & & & \\
\hline $6 \mathrm{StN}$ & & .461 & 340 & .619 & .531 & & (2) & (2) & & $a$ & 웅 & \\
\hline 7 EctEct & & 538 & 376 & .718 & .635 & 595 & & & & & & \\
\hline $8 \mathrm{SphBr}$ & & 626 & .368 & 659 & .463 & 542 & 623 & & & & & \\
\hline 9 StP & & & .508 & .358 & .490 & 657 & .335 & & & & 2 & \\
\hline $10 \mathrm{PmP}$ & & & .428 & & .441 & .563 & .353 & 365 & .731 & & & \\
\hline 11 govcm & & & & & & .527 & & .393 & .524 & & & \\
\hline $12 \mathrm{PdPm}$ & & & & & & & & & & & & \\
\hline
\end{tabular}

\begin{tabular}{|c|c|c|c|c|c|c|c|c|c|c|c|c|}
\hline FEMALES & 1 & 2 & 3 & 4 & 5 & 6 & 7 & 8 & 9 & 10 & 11 & 12 \\
\hline $1 \mathrm{AuAu}$ & & & & (당 & & & & & & & & \\
\hline $2 \mathrm{StN}$ & .409 & & & - & 8 & & 6 & & & & & \\
\hline $3 \mathrm{SmSm}$ & .540 & .481 & & & & & & & & & & \\
\hline $4 \mathrm{StP}$ & .554 & .557 & .472 & & & $\mathrm{O}$ & & & & & & \\
\hline $5 \mathrm{PmP}$ & .444 & .591 & 693 & .771 & & 0 & & ? & & & & \\
\hline $6 \mathrm{BP}$ & 597 & 607 & 708 & 879 & .884 & & 0 & & & & & \\
\hline 7 gocid & .458 & .544 & .616 & 708 & 739 & 807 & & & & & & \\
\hline 8 EctEct & .657 & .671 & 548 & .666 & 595 & 728 & .796 & & & & & \\
\hline 9 govcm & .415 & 454 & 564 & 727 & .714 & .834 & .873 & .649 & & & & \\
\hline $10 \mathrm{BSt}$ & .545 & .467 & .792 & .523 & .803 & .836 & 708 & .602 & 70 & & & \\
\hline $11 \mathrm{SphBr}$ & 551 & .694 & 477 & .566 & .431 & 576 & .613 & .744 & .492 & 430 & & \\
\hline $12 \mathrm{PdPm}$ & & -.467 & -509 & & & & & & & & & \\
\hline
\end{tabular}

Fig. 3. Diagram of correlation coefficients for skull dimensions in adult bison. Only statistically significant coefficients i.e. $r \geqslant 0.32$ have been given. 
and also breadth of the viscerocranium $(S \mathrm{mSm})$ in seven pairs; length of toothless margin $(P m P)$ - in six; breadth of neurocranium ( $A u A u$ ) -in five; length of base of skull $(B P)$ and length of base of viscerocranium $(S t P)$ - in four; height of neuroeranium $(S p h B r)$, length of base of neurocranium $(B S t)$ and also length of toothrow $(P d P m)-$ in three; interorbital breadth (EctEct) and height of viscerocranium (StN) - in two pairs.

During the postnatal life of bison the values of the majority of correlation coefficients decrease to a greater or lesser degree. In some cases, however, the correlation between skull dimensions is maintained on an unvarying level. The following are pairs of parameters which, in both sexes, exhibit, a constantly high correlation during postnatal life: length of base of skull and length of mandible (BP-gocid), length of base of neurocranium and length of base of viscerocranium (BSt-StP), length of base of viscerocranium and height of mandible (StP-govcm), length of toothless margin and height of viscerocranium (PmP-StN) and in addition, in males only: length and height of viscerocranium $(S t P-S t N)$. In females, in addition to the above pairs, in common with males, there are the 21 following pairs exhibiting high correlation $(r>0.6)$ throughout the animals' life: pairs of length of base of skull $(B P)$ with: BSt, PmP, SnaSm, govcm; pairs of length of toothless margin $(P m P)$ with: EctEct, $S m S m, A u A u, S p h B r, S t N$; paris of the mandibular condyle (govem) with gocid, EctEct, SmSm, AuAu, SphBr; and in addition the pairs PdPm-StN, gocid-EctEct, gocid-SphBr.

The pleiads constructed (Fig. 4) for adult males and females give the closest visual idea of dimorphic differences in the persistence of correlation connections.

With correlation level defined by $r>0.8$ in males these is only one pair: $B P$-gocid, whereas in females there are others in addition to the foregoing: BP-BSt BP-StP, BP-PmP, BP-govcm, govcm-gocid and BSt$P m P$. It can be seen that the base of the skull $(B P)$ is engaged in many of them. After reducing correlation level to $r>0.6$ the number of pairs increases slightly in males, primarily those connected with dimensions of the neurocranium. In females there are far more of these pairs. After further reduction of correlation level to $r>0.4$ only 17 pairs out of 66 occur in males, while in females only certain pairs connected with $P d P m$ are missing. Finally with the lowest degree of correlation, that is, in pleiads containing pairs characterized by the lowest coefficients, as long as they are significant, there are only 9 pairs (with $P d P m$ ) missing from the complete set, while in males there are 31 pairs, chiefly connected with both mandibular dimensions, toothrow length and breadth of viscerocranium. Thus the dropping out of features from 
Young males

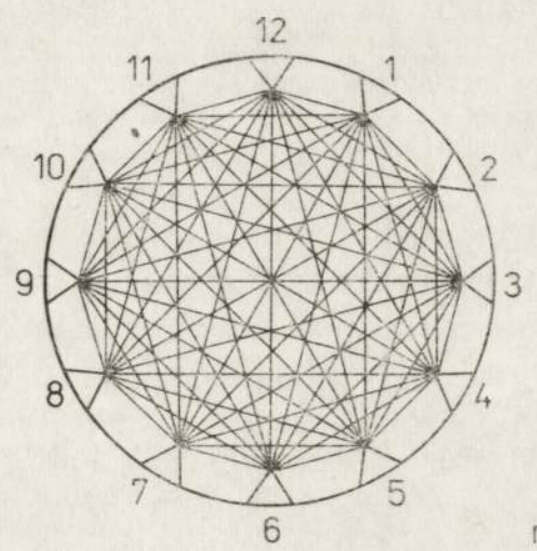

$r>0.6$

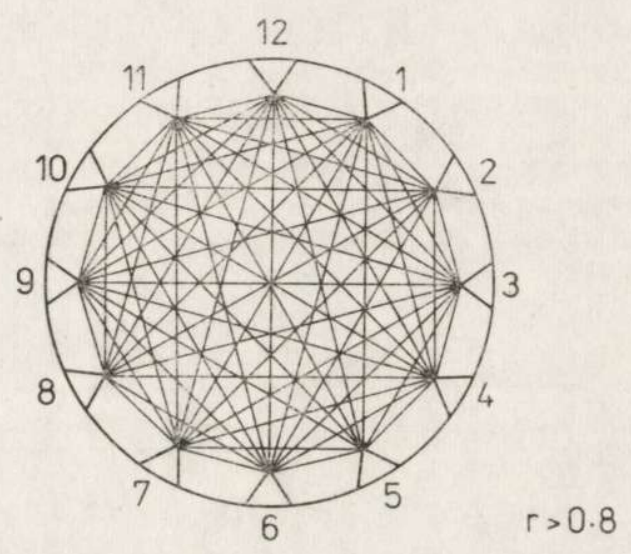

Young females
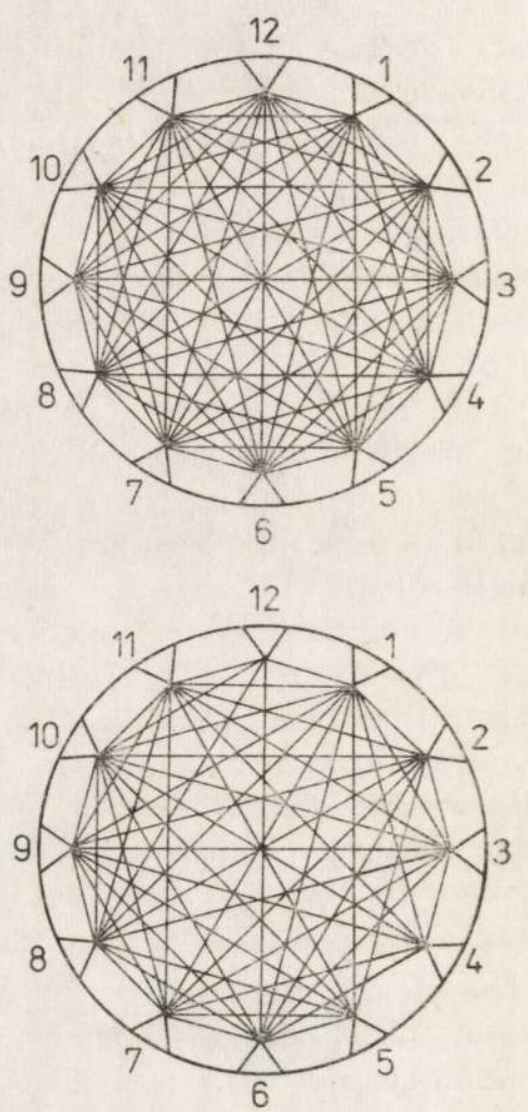

govcm

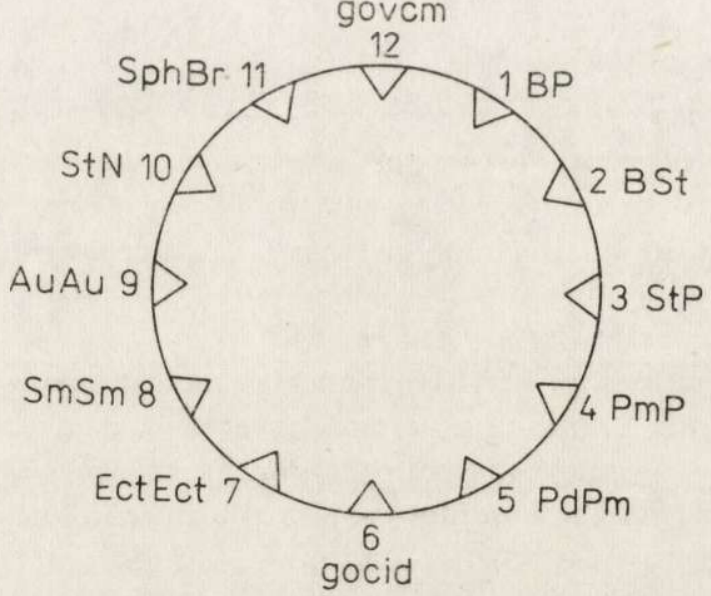

Fig 4. Concluded on page 360 . 


\section{Adult males}
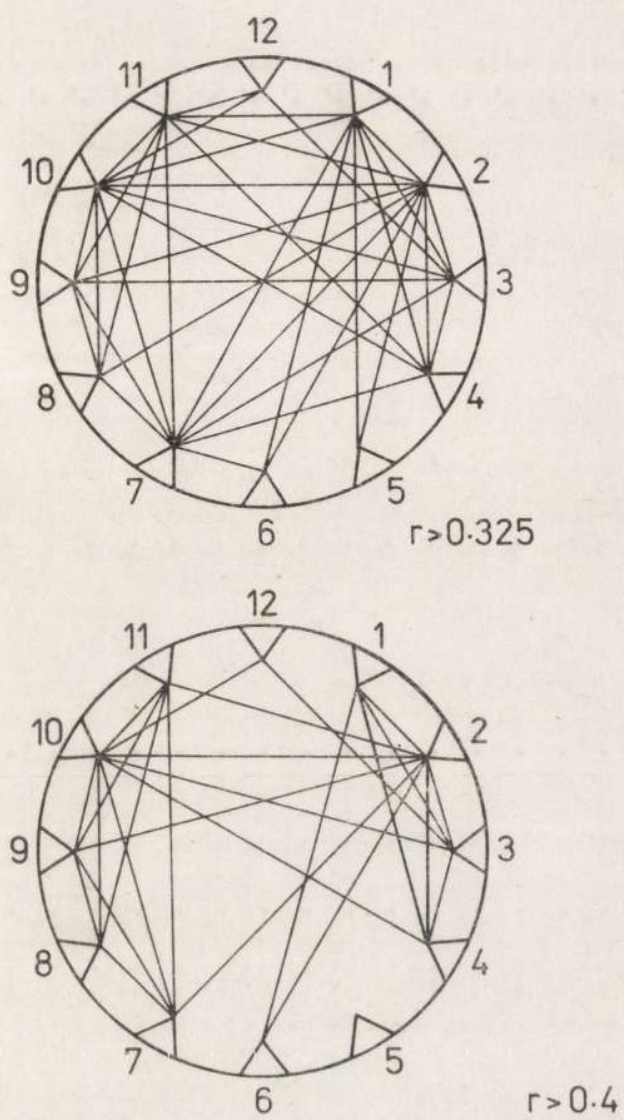

\section{Adult females}
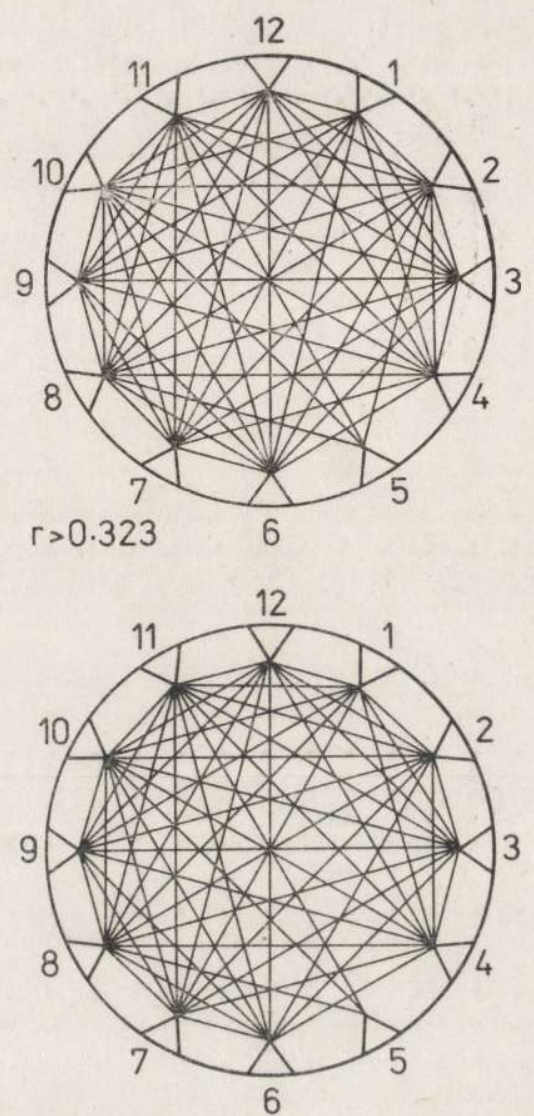

Concluded on page 360 .

the pleiads is in the first place delayed in females in relation to males, and in second place the order in which they drop out is in the main different in the two sexes.

\section{DISCUSSION}

The bison skull at no time during the period of postnatal life studied is a finally formed structure, as far as size and proportions of its dimensions are concerned. At the juvenile age they increase more or less proportionately, resulting in isometric growth of the skull. Allometric growth in adult animals is due to the lack of synchronization in enlargement of different dimensions. In the case of European bison, however, 
Adult males
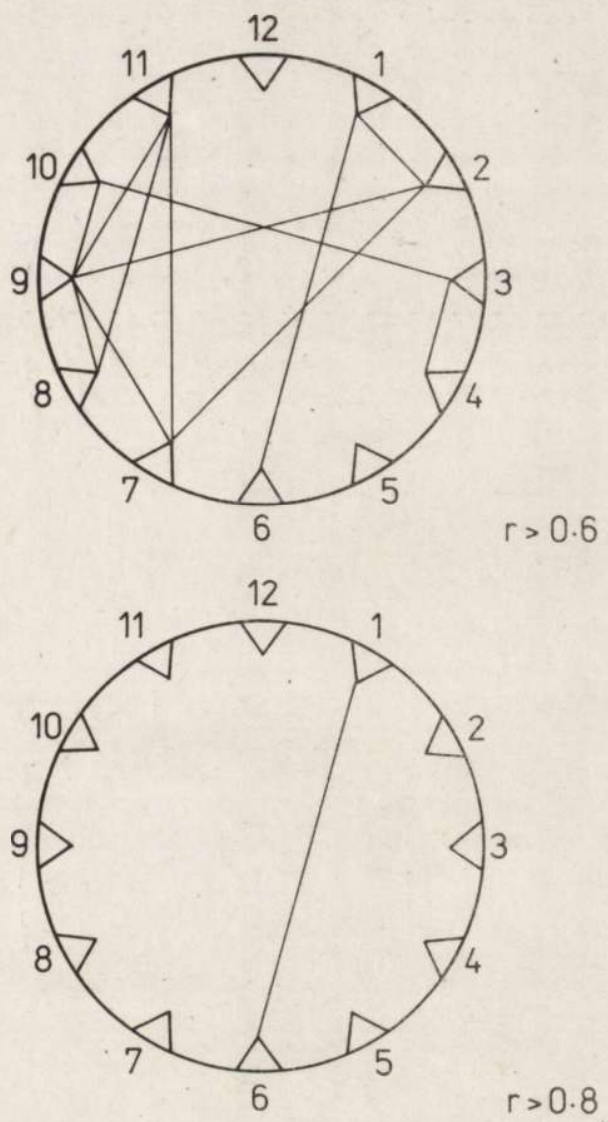

Adult females
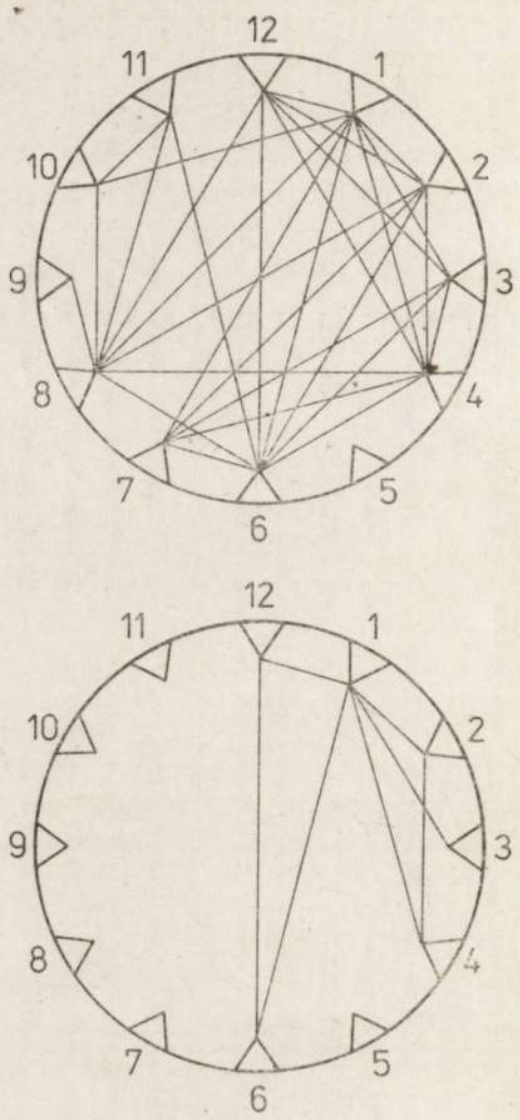

Fig. 4. Pleiads of correlation coefficients.

this observation can not be applied to all dimensions. For instance during the juvenile age the female mandible exhibits tendencies to allometric growth, whereas in adult females both its dimensions are among some of the better correlated parameters. The reserve applies during postnatal life of males.

The onto- and phylogenetic development of the mammal mandible is connected with the development of the viscerocranium, with which it is functionally more closely connected than with the neurocranium. Its growth and shape is most significantly affected first by the masticatory muscle system and then the kind of dentition, and only secondarily by the character of movements in the temporomandibular joint. This joint in ruminants has reached a high degree of biomechanical perfection owing to its eight-shaped movements and its being drawn upwards. 
The well-expressed anisognathism and the non-contacting character of this joint is also of significance.

It must be assumed that the dimorphic differences observed in development of the bison mandible forming inter alia what are known as tertiary sexual characters on the mammal's head, result from efforts towards maximum efficiency of the mandibular joint.

When sex is unknown the taxonomic value of the bison mandible is only negligible. In smaller mammals such as the polecat the mandible is of greater value. Even in material not segregated according to sex, the mandible is highly correlated with skull dimensions ( $\mathrm{Buch}$ alc z y k \& R u precht, 1977). In shrews however (R u precht, 1971) the mandibular condyle is distinguished by low correlation.

In adult male bison insignificant or low correlations occurring more vften than in females, apply particularly to parameters of the viscerocranium. This is undoubtedly closely connected with the stabilizing development of the mandible in males. The conclusion is thus reached that the neurocranium in bison males has more synchronous growth than the viscerocranium. Tests of significance showed that correlation coefficient for adult females are in many cases greater than in males of the same age. The majority of parameters with better correlation in females belong to the viscerocranium. Thus the viscerocranium and mandible of adult female bison are characterized by the more isometric development than in males.

Authors dealing with correlation of skull parameters in the polecat (B uchalczyk \& Ruprecht, 1977), muskrat (Ruprecht, 1974), hare (Ca boń-R a czyńska, 1964) found a decrease progressing with age in reciprocal correlations of skull measurements. In European bison, particularly in females, at least in half of all parameters a high degree of correlation is maintained such as during the period of juvenile development. In the first place high correlation in females is maintained in the case of almost all measurements of length. Height and breadth of the viscero- and neurocranium, on the other hand, exhibit few high correlations. In adult males there are far fewer characters with high correlation.

Length of the toothrow differs in the whole material in adult males and females in respect of complete absence of significant correlation with other dimensions, apart from a low and negative correlation of this parameter with the height and breadth of the viscerocranium in females. This is a completely normal phenomenon when it is remembered that the buccal teeth complete development far earlier than the skeleton. 


\section{REFERENCES}

1. Buchalczyk T. \& Ruprecht A. L., 1977: Skull variability of Mustelc putorius Linnaeus, 1758. Acta theriol., 22: 87-120.

2. Ca boń-R a czyńska K., 1964: Correlations of skull measurement of Lepus europeus Pallas, 1778. Acta theriol., 8: 207-216.

3. Czekanowski J., 1913: Zarys metod statystycznych w zastosowaniu de antropologii. Pr. TNW: 1-228. Warszawa.

4. Duerst J. U., 1926: Vergleichende Untersuchungsmethoden am Skelett be: Säugern. Urban and Schwarzenberg, 7: 125-530. Berlin-Vien.

5. Empel W., 1962: Morphologie des Schädels von Bison bonasus (Linnaeus 1758). Acta theriol., 6: 53-111.

6. Kanep S. V., 1967: A biometric study of skull characters in several grey voles of USSP fauna. Acta theriol., 12: 111-134.

7. P ta sińska-U r bańska M., 1972: Badania współzależności wymiarów powiek, oczodolu i gałki ocznej. Folia morph., 31: 235-239.

8. Ruprecht A. L., 1971: Taxonomic value of mandible measurements in Soricidae (Insectivora). Acta theriol., 16: 341-357.

9. Ruprecht A. L., 1972a: Correlation structure of skull dimension in hedge. hogs. Acta theriol., 17: 419-442.

10. Ruprecht A. L., 1972b: A case of hypertrophy of tuberculum musculare in Bison bonasus (Linnaeus, 1758). Acta theriol., 17: 493-498.

11. Ruprecht A. L., 1974: Craniometric variations in central European populations of Ondrata zibethica (Linnaeus, 1766). Acta theriol., 19: 463-507.

12. Strzałko J. \& Malinowski A., 1972: Mięśnie żwaczowe a proporcjє czaszki u naczelnych. Folia morph., 31: 227-233.

13. Terentev V., 1943: Korelacji indeksov černoj ljaguški, Rana ridibundo Pall. Zool. Ž., 22: 267-273.

14. Wyrost P. \& Kucharczyk J., 1967: Versuch der Bestimmung der Wideristhöhe der Hundes mittels der inneren Hirnhöhlenlänge. Acta theriol. 12: $105-110$.

15. Ża biński 3. (Ed.), 1947-65: Pedigree book of the European Bison. Państw. Wyd. Nauk: 1-317. Warszawa.

16. Żabiński J. \& Raczyński J. (Eds.), 1972: European bison pedigree book 1965-69. Państw. Wyd. Nauk: 1-78. Warszawa.

Accepted, April 10, 1980. 
Franciszek KOBRYÑCZUK i Tadeusz ROSKOSZ

\section{WSPOEZALEŻNOSC WYMIARÓW CZASZKI ŻUBRA}

\section{Streszczenie}

W oparciu o materiał 84 żubrów, Bison bonasus (Linnaeus, 1758) z rezerwatów polskich, zbadano korelacje między 12 podstawowymi wymiarami czaszki, w zależności od wieku i płci zwierząt (Tabela 1, Ryc. 1). Współczynniki korelacji uporządkowano przy pomocy diagramów Czekanowskiego (1913) i plejad Terentieva (1943) (Ryc. 2, 3, 4). Stwierdzono wysoką współzależność parametrów czaszki u osobników młodych. U żubrów dorosłych wartości części tych wspólczynników obniżają się $\mathrm{w}$ porównaniu z okresem młodzieńczym (Tabela 2). Niektóre jednak korelacje, szczególnie u samic pozostają na wysokim poziomie przez całe życie. Stwierdzono du̇ży dymorfizm płciowy w rozwoju żuchwy u żubrów obu płci. U dorosłych samic wymiary żuchwy są dobrze skorelowane z innymi parametrami czaszki, natomiast u rówieśnych samców, poza długością podstawy czaszki i długością mózgowioczaszki, żuchwa traci swe związki korelacyjne z pozostałymi wymiarami czaszki. Długość szeregu zębowego szczęki u samców we wszystkich przypadkach, u samic z dwoma wyjątkami, w wieku dojrzałym również nie jest zsynchronizowana z paramterami cżaszki. W niektórych przypadkach współczynniki korelacji wymiarów czaszki dorosłych samic są istotnie większe niż u samców (Tabela 2). Przeważnie wyższe u samic niż u samców korelacje spotykamy między wymiarami trzewioczaszki. 